\title{
Severe Acute Hepatitis E in a Woman with an Autoimmune Background
}

\section{Hepatite E Aguda Severa em Mulher com História Auto-imune}

\author{
Maria S.J. NASCIMENTO $\rrbracket^{1,2}$, Madalena ALMEIDA-SANTOS ${ }^{3}$, Maria FERNANDES ${ }^{3}$, Fernando MALTEZ ${ }^{4}$, Sara LINO ${ }^{4}$, \\ Martin D. CURRAN ${ }^{5}$, João R. MESQUITA ${ }^{2,6}$
}

Acta Med Port 2020 Jun;33(6):425-428 - https://doi.org/10.20344/amp.10429

\section{ABSTRACT}

Hepatitis E virus genotype 3 infections are normally asymptomatic in immunocompetent individuals. Symptomatic cases of acute icteric hepatitis $E$ are seldom observed among women, younger men and children but are particularly seen in middle-aged/elderly men. We report a case of severe acute hepatitis $E$ caused by genotype 3 in an immunocompetent 40-year-old woman that required prolonged hospitalization. Her medical history included an autoimmune background, namely atrophic gastritis and Graves' disease. She presented an extensive hepatic necrosis as revealed by the high levels of aminotransferases (ALT $4893 \mathrm{U} / \mathrm{L} ;$; AST $3138 \mathrm{U} / \mathrm{L}$ ). She showed also a coagulation disorder (prothrombin time; INR =1.33). Serological markers for hepatitis viruses $A$, B and $C$ were negative but serum was positive for hepatitis E virus RNA. Sequencing and phylogenetic analysis revealed that the hepatitis $E$ virus strain belonged to subgenotype $3 a$. This is suggestive of an association between the severe acute hepatitis $E$ virus genotype 3 infection and the autoimmune background.

Keywords: Acute Disease; Autoimmune Diseases; Hepatitis E; Hepatitis E virus

\section{RESUMO}

As infeções pelo vírus da hepatite $\mathrm{E}$ do genótipo 3 são normalmente assintomáticas em indivíduos imunocompetentes. Os casos sintomáticos de hepatite $\mathrm{E}$ aguda ictérica são raramente observados em mulheres, crianças e jovens adultos, sendo mais frequentes em homens de meia-idade e idosos. Descrevemos um caso de hepatite aguda severa com hospitalização prolongada numa mulher imunocompetente de 40 anos causada pelo vírus da hepatite $E$ do genótipo 3 . Da sua história clínica destacavam-se doenças autoimunes, nomeadamente gastrite atrófica e doença de Graves. A mulher apresentava uma necrose hepática grave, revelada pelos altos níveis de aminotransferases (ALT 4893 U/L; AST 3138 U/L), e distúrbios de coagulação (tempo de protrombina; INR = 1,33). Os marcadores serológicos para os vírus das hepatites $A, B$ e $C$ foram negativos; a pesquisa de ARN do vírus da hepatite $E$ foi positiva no soro. A sequenciação e a análise filogenética revelaram que o vírus da hepatite $\mathrm{E}$ em causa pertencia ao subgenótipo $3 a$. Os autores sugerem uma associação entre a infeção aguda severa causada pelo vírus da hepatite $\mathrm{E}$ genótipo 3 e o historial autoimune da mulher. Palavras-chave: Doença Aguda; Doenças Autoimunes; Hepatite E/imunologia; Vírus da Hepatite E

\section{INTRODUCTION}

More than ten years have passed since the first reports of autochthonous hepatitis E virus (HEV) infections in high-income countries but viral pathogenesis and clinical aspects remain to be clarified concerning HEV genotype 3 , the one responsible for the majority of the locally-acquired (autochthonous) cases in Europe and in many other industrialized countries. ${ }^{1,2}$ It is now known that autochthonous HEV genotype 3 infections are very common in these countries, based on several studies reporting high HEV seroprevalence rates. ${ }^{1,2}$ Despite this, hepatitis $E$ in high-income countries remains undetected or undiagnosed. ${ }^{3}$ Moreover, in Europe both the number of autochthonous HEV infections as well as the number of HEV-related hospitalisations has been increasing in the last decade. ${ }^{4}$ Food is the major route of transmission of HEV genotype 3 in Europe, with consumption of raw (or under-cooked) pig and wild boar meat products being the main source of infection. But other foods have been suspected as well. ${ }^{5}$

In Portugal, the presence of HEV in humans, animals and the environment has been described during the past years. Reports of autochthonous cases of hepatitis $E$ with distinct clinical presentations that varied from neurological complications, to chronic presentations and autoimmune disorders were documented. ${ }^{6-9}$ Moreover, epidemiological studies have demonstrated the presence of antibodies against HEV in the Portuguese population of all ages, from a wide array of settings and throughout the country, ${ }^{10-14} \mathrm{con}$ firming that HEV is endemic in Portugal. ${ }^{14}$ Moreover, molecular studies in pigs and wild boar revealed the presence and circulation of HEV genotype 3 in these animals throughout the national territory. ${ }^{15-17}$ HEV genotype 3 has also been detected in wastewater from treatment plants in Portugal. ${ }^{18}$

Infections with HEV genotype 3 are typically self-limited and asymptomatic in immunocompetent individuals. ${ }^{3}$ Symptomatic cases of acute icteric hepatitis occur markedly in middle-aged/elderly men and are rare in healthy women,

\footnotetext{
1. Laboratório de Microbiologia. Departamento de Ciências Biológicas. Faculdade de Farmácia. Universidade do Porto. Porto. Portugal.

2. Epidemiology Research Unit. Instituto de Saúde Pública. Universidade do Porto. Porto. Portugal.

3. Laboratório de Patologia Clínica. Hospital Curry Cabral. Centro Hospitalar Lisboa Central. Lisboa. Portugal.

4. Serviço de Doenças Infeciosas. Hospital Curry Cabral. Centro Hospitalar Lisboa Central. Lisboa. Portugal.

5. Clinical Microbiology and Public Health Laboratory. Addenbrooke's Hospital. Cambridge. United Kingdom.

6. Instituto de Ciências Biomédicas de Abel Salazar. Universidade do Porto. Porto. Portugal.

$\triangle$ Autor correspondente: Maria S.J. Nascimento. saojose@ff.up.pt.

Recebido: 20 de fevereiro de 2018 - Aceite: 25 de março de 2019 | Copyright @ Ordem dos Médicos 2020
} 
younger men and children. ${ }^{1,19,20}$ One of the most curious aspects of HEV genotype 3 infection is the association with numerous extra-hepatic manifestations that may develop either in acute or chronic infections. However, the role of genotype 3 in these disorders is yet to be clarified, including the autoimmune extra-hepatic manifestations. ${ }^{21}$

The present study reports a case of severe acute hepatitis $E$ caused by genotype 3 in an immunocompetent 40-year-old woman with a medical history of autoimmune disorders that required hospitalization for 14 days.

\section{CASE REPORT}

On the $15^{\text {th }}$ December 2015, a 40-year-old woman presented with exuberant jaundice to the Emergency Unit of a Hospital in Lisbon, Portugal. One week before, she had started with nausea, abdominal pain, having dark urine and pale colored stools. She had no history of drug use or sexual risk behavior, occupational risk to $\mathrm{HBV}$ or $\mathrm{HCV}$, household contact with a person with hepatitis A, travel to endemic areas of hepatitis A or E. She denied contact with animals and consumption of herbal products, wild mushrooms or recent introduction of pharmaceuticals (antibiotics, anti-inflammatory drugs and analgesics). Her medical history included autoimmune disorders, namely autoimmune atrophic gastritis and Graves' disease, in remission. Abdominal ultrasonography and radiography showed no changes, and electrocardiography was normal as well. Blood tests revealed a coagulation disorder (prothrombin time; INR = 1.33). The normal level of ceruloplasmin excluded Wilson's disease. Antinuclear auto-antibodies (ANA) were only slightly positive (titer 1:160) but all other autoimmune markers were negative. Liver function tests (Table 1) showed a marked elevation of hepatic enzymes with alanine aminotransferase (ALT) values higher than aspartate aminotransferase (AST) (4893 IU/L versus 3138 IU/L, respectively) a pattern suggestive of viral hepatitis. Serological markers of acute infection for hepatitis $A$, $B$ and $C$ viruses, Epstein-Barr virus and cytomegalovirus were all negative. She also tested negative for Coxiella burnetii and Rickettsia. Since the patient's history was not suspicious for hepatitis E, antibodies anti-HEV IgM and IgG were not searched for. HEV RNA was only later detected (after discharge) in archived serum collected on admission. Real-time reverse transcription PCR (RT-PCR) with

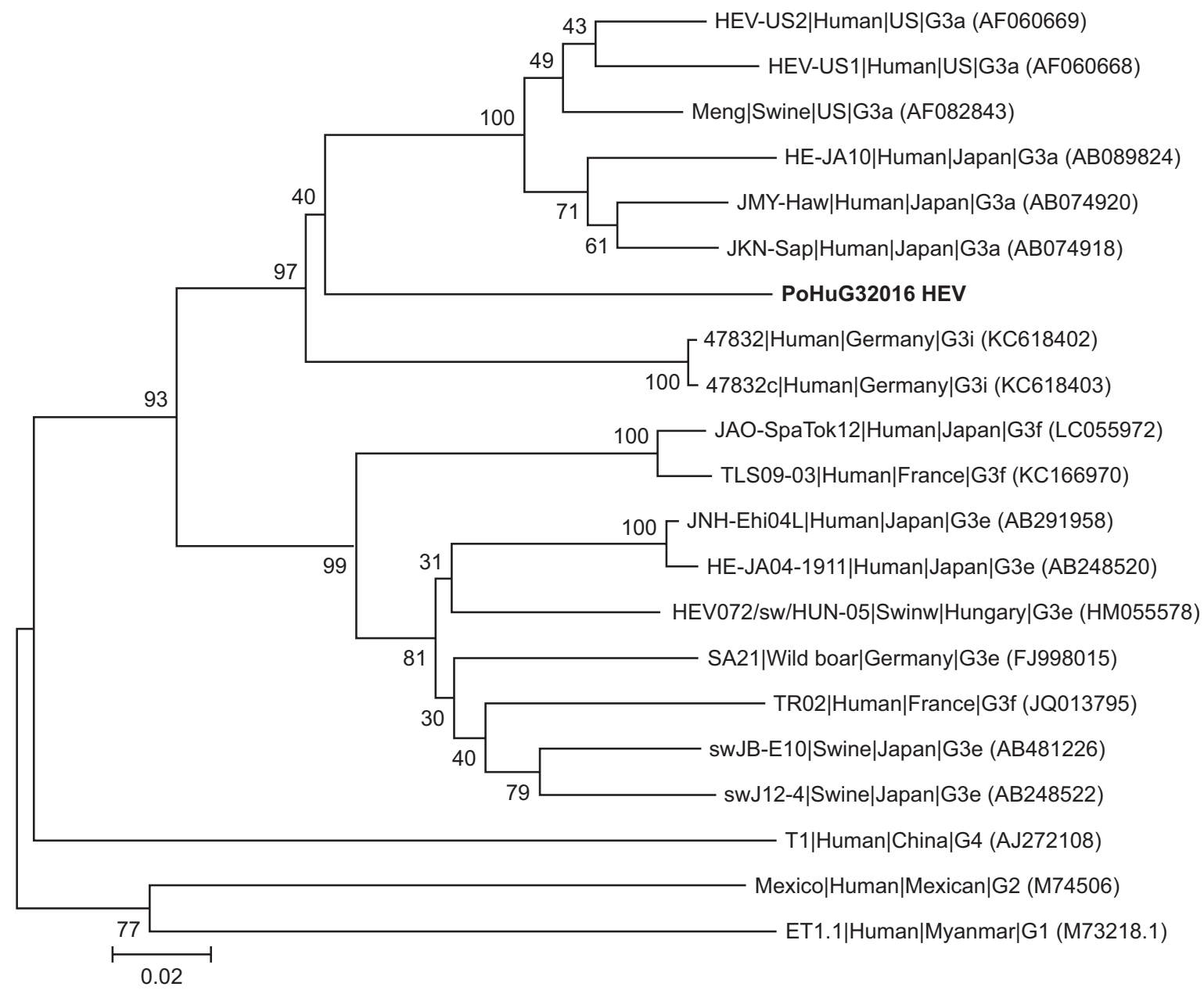

Figure 1 - Phylogenetic tree based on partial RNA-dependent RNA-polymerase region of open reading frame 1 (330 bp) using neighborjoining method based on the Jukes-Cantor model and 1000 bootstrap resamplings. PoHuG32016HEV represents the sequence characterized in this study and is represented in bold. Scale bar indicates substitutions per nucleotide position. Sequences are defined in tree as Strain|Host|Origin|Subgenotype (accession number). 
primers/probe targeting the open reading frame (ORF) 2 region $^{22}$ was used for HEV RNA detection. For the genetic characterization of the HEV strain, a 330 nucleotide partial sequence in ORF 1 region was amplified with nested broadspectrum RT-PCR. ${ }^{23}$ The phylogenetic analysis indicated that the sequence retrieved from the woman clustered with HEV genotype 3, subgenotype 3a sequences (Fig. 1).

The clinical evolution of the woman was favorable and she was discharged on the $29^{\text {th }}$ December, 14 days after admission. At discharge, prothrombin time was already normal (INR $=0.97$ ) and bilirubin and transaminases were decreasing showing almost normal values on the follow-up analysis of $25^{\text {th }}$ January (Table 1 ).

\section{DISCUSSION}

The present report describes a case of autochthonous severe acute hepatitis $E$ caused by genotype 3 in a 40 year old woman with an autoimmune background. Although acute icteric hepatitis caused by HEV genotype 3 is mainly observed among men aged over 60 , this middle-aged woman developed a severe hepatitis with an extensive hepatic necrosis as revealed by the high levels of aminotransferases (> $3000 \mathrm{UI} / \mathrm{L}$ ) that required 14 days of hospitalization. Cases of acute hepatitis $E$ have been described in women associated with concomitant signs of autoimmunity ${ }^{9,24}$ and also with signs of hyperthyroidism (including Grave's disease), subclinical hyperthyroidism and subacute thyroiditis. ${ }^{25-28}$ In the present case, the woman's severe clinical course was only accompanied by a slightly positive ANA titer while the other autoimmune markers were absent, which ruled out an autoimmune hepatitis. Bearing in mind that the medical history of this patient included Graves' disease (although in remission), liver dysfunction (causing severe icteric hepatitis) in a context of hyperthyroidism due to a relapse of Graves disease cannot be excluded. Unfortunately, thyroid hormone levels (T3, T4 and TSH) were not investigated in the patient. It would be interesting to check the levels of thyroid hormones since liver dysfunction has been observed in patients with hyperthyroidism ranging from mild liver test abnormalities to deep jaundice. ${ }^{29}$

It seems very unlikely that HEV genotype 3 had been the sole responsible for the exuberant clinical manifestations since this genotype is rarely associated with severe disease in healthy women. The pathogenesis of HEV infection is still unclear and involves a complex interplay between the virus and its host, particularly the host immune system. ${ }^{30}$ So we hypothesize that the patient's autoimmune background could have been a contributing factor for severe hepatitis E. However, since no ANA or other autoimmune markers were screened for upon discharge or during follow-up, a definitive association between the course of hepatitis $E$ and autoimmunity cannot be established. Nonetheless, such an association has been documented in a previous case report from Portugal. ${ }^{9}$

In conclusion, the present clinical case highlights the need to include HEV (along with HAV, HBV and HCV) in the differential diagnosis of patients presenting acute hepatocellular damage in industrialized countries, regardless of travel history, as autochthonous HEV infections have been increasing in high-income countries.

\section{PROTECTION OF HUMANS AND ANIMALS}

The authors declare that the procedures were followed according to the regulations established by the Clinical Research and Ethics Committee and to the Helsinki Declaration of the World Medical Association.

\section{DATA CONFIDENTIALITY}

The authors declare having followed the protocols in use at their working center regarding patients' data publication.

\section{PATIENT CONSENT}

Obtained.

\section{CONFLICTS OF INTEREST}

All authors report no conflict of interest.

\section{FUNDING SOURCES}

This research received no specific grant from any funding agency in the public, commercial, or not-for-profit sectors.

Table 1 - Laboratory parameters on admission and at discharge (14 days of hospitalization)

\begin{tabular}{lcccc}
\hline Blood test results & $\begin{array}{c}\text { On admission } \\
\text { (December 15) }\end{array}$ & $\begin{array}{c}\text { At discharge } \\
\text { (December 29) }\end{array}$ & $\begin{array}{c}\text { Follow-up } \\
\text { (January 25) }\end{array}$ & Reference values \\
\hline Haemoglobin (g/dL) & 14.4 & 13.4 & ND & $12-15.6$ \\
Leukocytes (x109/L) & 6.6 & 5.2 & ND & $4.5-11.0$ \\
PT (INR) & 1.33 & 0.97 & 49 & 5.1 \\
AST (U/L) & 3138 & 131 & 81 & $0.0-54.0$ \\
ALT (U/L) & 4893 & 299 & 51 & $9.0-36.0$ \\
GGT (U/L) & 89 & 61 & 2.33 & $0.2-1.2$ \\
Total BIL (mg/dL) & 19 & 15.57 & 1.37 & $0.0-0.50$ \\
Direct BIL (mg/dL) & 14 & 10.15 & ND & $125-220$ \\
LDH (IU/L) & 832 & 168 & ND & $37-98$ \\
ALP (U/L) & 158 & 118 & 49.0 \\
\hline
\end{tabular}

PT: prothrombin time; AST: aspartate aminotransferase; ALT: alanine aminotransferase; GGT: gamma-glutamyl transpeptidase; BIL: bilirubin; LDH: lactate dehydrogenase; ALP: alkaline phosphatase. 


\section{REFERENCES}

1. Kamar N, Bendall R, Legrand-Abravanel F, Xia NS, ljaz S, Izopet J, et al. Hepatitis E. Lancet. 2012;30:2477-88.

2. Hoofnagle JH, Nelson KE, Purcell RH. Hepatitis E. N Engl J Med. 2012;367:1237-44.

3. Dalton HR, Saunders M, Woolson KL. Hepatitis E virus in developed countries: one of the most successful zoonotic viral diseases in human history? J Virus Erad. 2015;1: 23-9.

4. Aspinall EJ, Couturier E, Faber M, Said B, ljaz S, Tavoschi L, et al, on behalf of the country experts. Hepatitis $E$ virus infection in Europe: surveillance and descriptive epidemiology of confirmed cases, 2005 to 2015. Euro Surveill. 2017;22:pii=30561.

5. Ricci A, Allende A, Bolton D, Chemaly M, Davies R, Salvador P, et al. Public health risks associated with hepatitis $E$ virus (HEV) as a foodborne pathogen. EFSA Journal. 2017;15:4886-15.

6. Duque V, Ventura C, Seixas D, da Cunha S, Meliço-Silvestre A. First report of acute autochthonous hepatitis E in Portugal. J Infect Dev Ctries. 2012;13:201-3.

7. Santos L, Mesquita JR, Rocha Pereira N, Lima-Alves C, Serrão R, Figueiredo $\mathrm{P}$, et al. Acute hepatitis $\mathrm{E}$ complicated by Guillain-Barre syndrome in Portugal, December 2012--a case report. Euro Surveill. 2013;22:pii: 20563.

8. Breda F, Cochicho J, Mesquita JR, Bento A, Oliveira RP, Louro E, et al. First report of chronic hepatitis $E$ in renal transplant recipients in Portugal. J Infect Dev Ctries. 2014;15:1639-42.

9. Vieira CL, Baldaia C, Fatela N, Ramalho F, Cardoso C. Case of acute hepatitis $\mathrm{E}$ with concomitant signs of autoimmunity. World $\mathrm{J}$ Hepatol. 2013;27:152-5.

10. Queirós L, Condeço J, Tender A, Mateus M, Teixeira A, Pascoal H. Seroprevalência de anticorpos para o vírus da hepatite $\mathrm{E}$ na região norte de Portugal (numa população de dadores). Acta Med Port. 1997; 10:447-53.

11. Macedo G, Pinto T, Sarmento JA, Vale AM, Ribeiro T. Primeira avaliação da seroprevalência do vírus da hepatite $E$ no norte de Portugal. Acta Med Port. 1998;11:1065-8.

12. Mesquita JR, Abreu-Silva J, Sousa JC, Aguiar A, Nascimento MS. Evidence of autochthonous hepatitis $E$ in a Portuguese pediatric cohort, 1992-1995. J Med Virol. 2016;88:919-21.

13. Teixeira J, Mesquita JR, Pereira SS, Oliveira RM, Abreu-Silva J, Rodrigues A, et al. Prevalence of hepatitis $E$ virus antibodies in workers occupationally exposed to swine in Portugal. Med Microbiol Immunol. 2017;206:77-81

14. Nascimento MS, Pereira SS, Teixeira J, Abreu-Silva J, Oliveira RM, Myrmel M, et al. A nationwide serosurvey of hepatitis $E$ virus antibodies in the general population of Portugal. Eur J Public Health. 2018;28:720 24.

15. Berto A, Mesquita JR, Hakze-van der Honing R, Nascimento MS, van der Poel WH. Detection and characterization of hepatitis $E$ virus in domestic pigs of different ages in Portugal. Zoonoses Public Health. 2012;59:477-81.

16. Mesquita JR, Oliveira RM, Coelho C, Vieira-Pinto M, Nascimento MS. Hepatitis E virus in sylvatic and captive wild boar from Portugal. Transbound Emerg Dis. 2016;63:574-8.

17. Gonçalves D, Pereira-Vaz J, Duque V, Bandeira V, Fonseca C, Donato $A$, et al. First serological evidence on endemicity of HEV infection in wild boar (sus scrofa) populations from Portugal. Virol Sin. 2018;33:197-200.

18. Matos A, Mesquita JR, Gonçalves D, Abreu-Silva J, Luxo C, Nascimento MS. First detection and molecular characterization of hepatitis $E$ virus in water from wastewater treatment plants in Portugal. Ann Agric Environ Med. 2018;20:364-7.

19. Dalton HR, Bendall RP, Rashid M, Ellis V, Ali R, Ramnarace R, et al. Host risk factors and autochthonous hepatitis E infection. Eur J Gastroenterol Hepatol. 2011;23:1200-5.

20. Saint-Jacques $P$, Tissot-Dupont H, Colson P. Autochthonous infection with hepatitis $E$ virus related to subtype $3 a$, France: a case report. Ann Hepatol. 2016;15:438-41.

21. Bazerbachi F, Haffar S, Garg SK, Lake JR. Extra-hepatic manifestations associated with hepatitis $E$ virus infection: a comprehensive review of the literature. Gastroenterology Report. 2016;4:1-15.

22. Rolfe KJ, Curran MD, Mangrolia N, Gelson W, Alexander GJ, L'estrange $\mathrm{M}$, et al. First case of genotype 4 human hepatitis $\mathrm{E}$ virus infection acquired in India. J Clin Virol. 2010;48:58-61.

23. Johne R, Plenge-Bönig A, Hess $M$, Ulrich RG, Reetz J, Schielke A. Detection of a novel hepatitis $E$-like virus in faeces of wild rats using a nested broad-spectrum RT-PCR. J Gen Virol. 2010;91:750-8.

24. Nagasaki F, Ueno $Y$, Mano $Y$, Igarashi T, Yahagi K, Niitsuma H, et al. A patient with clinical features of acute hepatitis $E$ viral infection and autoimmune hepatitis. Tohoku J Exp Med. 2005;206:173-9.

25. Dumoulin FL, Liese $H$. Acute hepatitis $E$ virus infection and autoimmune thyroiditis: yet another trigger? BMJ Case Rep. 2012;pii:bcr1220115441.

26. Kong SJ, Min SK, Kim IK, Koo H, Park II, Han JP, et al. Two cases of acute hepatitis $\mathrm{E}$ in patients with hyperthyroidism. Korean J Gastroenterol. 2006;47:65-71.

27. Martínez-Artola Y, Poncino D, García ML, Munné MS, González J, García DS. Acute hepatitis $E$ virus infection and association with a subacute thyroiditis. Ann Hepatol. 2015;14:141-2.

28. Riveiro-Barciela M, Rodríguez-Frías F, Buti M. Hepatitis E virus: new faces of an old infection. Ann Hepatol. 2013;12:861-70.

29. Khemichian S, Fong TL. Hepatic dysfunction in hyperthyroidism. Gastroenterol Hepatol. 2011;7:337-9.

30. Lhomme S, Marion O, Abravanel F, Chapuy-Regaud S, Kamar N, Izopet J. Hepatitis E pathogenesis. Viruses. 2016;8.pii:E212. 